\title{
Influence of Manufacturing Processes in Deterioration of Ag-Cu Artefact Alloy
}

\author{
Abeer Gharib \\ Conservation Department, Faculty of Fine Arts, Minia University, Minia, Egypt
}

Email address:

Abeer.ibrahim@mu.edu.eg

\section{To cite this article:}

Abeer Gharib. Influence of Manufacturing Processes in Deterioration of Ag-Cu Artefact Alloy. International Journal of Archaeology. Vol. 8, No. 1, 2020, pp. 1-5. doi: 10.11648/j.ija.20200801.11

Received: December 10, 2019; Accepted: December 20, 2019; Published: January 4, 2020

\begin{abstract}
Ancient silver with about 2\% copper object is studied to determine manufacturing defects based on chemical and microscopic investigations. In this paper Bullion (silver-copper alloy) ink box inlays with enamel from the Museum of the faculty of applied arts in Cairo, Egypt has been investigated to identify manufacturing process and its effect on the ink deterioration. Scanning Electron Microscopy coupled with Energy Dispersive X-ray Spectrometry (SEM-EDS) method has been used on samples to reveal chemical composition of the alloys and the effect of various fabrication and thermal treatment. The results indicated that all samples were made of silver-copper alloys, other elemental corrosion layers have detected in contents such as $\mathrm{C}, \mathrm{O}, \mathrm{S}, \mathrm{Cl}, \mathrm{Si}, \mathrm{Na}, \mathrm{Ca}, \mathrm{Al}$. Fracture surfaces provide with important information helping to recognize failure causes, so the fracture surface investigation and etching by means of alcoholic ferric chloride was carried out for microstructural analysis. Scanning Electron Microscopy SEM-micrograph of etching sample showed pores and cracking propagation. Crack initiation usually appears at the object surface, and is generally produced by stress concentrators, producing rise to local plastic deformation or cracking and detachment of brittle precipitates. Local stress-strain concentration related to a variety of microstructural inhomogeneities. The X-ray diffraction analysis (XRD) confirmed the EDX analysis that the corrosion compounds consist of Montmorillonite $\mathrm{NaO}_{3}\left(\mathrm{Al}, \mathrm{Mg}_{2} \mathrm{Si}_{4} \mathrm{O}_{10}(\mathrm{OH})_{2} \mathrm{XH}_{2} \mathrm{O}\right.$, Atacamite $\mathrm{Cu} 2 \mathrm{Cl}(\mathrm{OH})_{3}$, Malachite $\mathrm{Cu}_{2} \mathrm{CO}_{3}(\mathrm{OH})_{2}$, Paratacamite $\mathrm{Cu}_{2} \mathrm{Cl}(\mathrm{OH})_{3}$, Cuprite $\mathrm{Cu}_{2} \mathrm{O}$, Acanthite $\mathrm{Ag}_{2} \mathrm{~S}$, Tenorite $\mathrm{CuO}$, Calcite $\mathrm{CaCO}_{3}$, Chlorargyrite $\mathrm{AgCl}$, Copper $\mathrm{Cu}$. Silver-copper alloys failed through corrosion process that produce brownish-black tarnish. This tarnish alters the aesthetic of the object. The corrosion layers of the object referred to long-term contamination and oxidation, which led to increase intergranular cracking, regions of ductile fracture, and brittle intergranular fracture.
\end{abstract}

Keywords: Silver-Copper Alloy, Art Work Defects, SEM-EDX, XRD, Plastic Deformation, Defects Analysis

\section{Introduction}

Application of silver to make various objects affected on the formation of an individual metalworking style that have been under influence of art of all regions and nations. Bullion alloy (silver -copper alloy) have been often used to production various decorative artefacts [1]. Cast silver alloyed with copper has been worked from at least the third millennium $\mathrm{BC}$, for making both functional and decorative objects. It is important to recognize the microstructures deformation in ancient cast silver object, product from the manufacturing process [2]. The metallic elements added to copper to procedure alloys alteration its corrosion behavior. The more noble $(\mathrm{Ag})$ accelerate the corrosion, while the most active $(\mathrm{Sn}, \mathrm{Zn}, \mathrm{Pb})$ helps its cathodic protection during a certain period in function of the environmental aggressiveness [3].

The examination of microstructure is one of the principal methods of estimating alloys to determine the effects of various manufacture and thermal treatments, evaluate the cause of failure. microstructure develop simultaneously with homogenization, preheat, annealing, or solution or precipitation heat treatment of the alloy [4].

Fatigue damage dependent on microstructural features like the grain size, the crystallographic orientation relationship, and the grain-boundary structure [5]. porosity, inclusions, constituent particles (insoluble phase formed during solidification), dispersoids (fine precipitate that forms during high-temperature thermal operations) [4].

Cold working is the deformation of a metal microstructure 
below its recrystallisation temperature. With cold working the desired shape is produced but the metal is strengthened (or strain-hardening). The strengthening is the result of the increasing number of dislocations. When stress exceeds the dislocation start to slip. Further increase of the applied stress, the deformation leads to a visible distortion of grains $[6,7]$.

In casting several types of defects may occur; as a result of unsuitable or unsatisfactory raw materials used in molding; or the application of unsatisfactory molding or casting practice by the individual worker or the use of improper tools $[8,9]$.

In this paper a Bullion ink box inlays with enamel from the Museum of the faculty of applied arts in Cairo, Egypt has been studied, the Bullion box dating to the nineteenth century 1945 but this need not necessarily be the date of manufacture. It had a temporarily inventoried with number $99 / 5$. it was 2 $\mathrm{cm}$ high, $8 \mathrm{~cm}$ diameter, $11 \mathrm{gm}$ weight.

The ink box is made from two parts Figure 1, the upper part is an ink box cover and the lower part is a box body. The ink box cover has been built up from sheet components brazed together to form outer and inner jackets, the outer sheet engraved with decorative channels or chased and inlaid with enamel. The lower part (box body) is made by casting.

The painted enamels were first made and developed during the Renaissance period in Limoges, France in the 15th century and later moved into Iran and other parts of the world. Painted Limoges enamels are unique and extraordinary as their figurative composition and creative achievements. These enamels are achieved from several layers of translucent or opaque glass powder of different compositions, which were carried out and fused in up to ten firing stages onto a thin copper plate. The fabrication of the painted enamels included the shaping of the copper base, applying counter-enamel and grounding and several layers of coloured enamel to product a picture [10].

The aim of this paper is evaluated the causes of failure due to manufacturing defects by investigation of Bullion box deterioration to illustrate the effect of manufacturing processes on the degradation of Bullion artefacts.

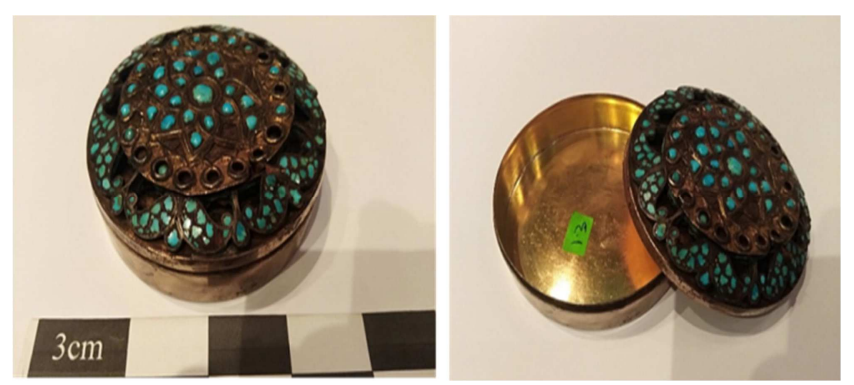

Figure 1. The ink box made from two parts and inlays with enamel.

\section{Materials and Methods}

\subsection{Scanning Electron Microscopy (SEM-EDX)}

Scanning electron microscopy (SEM) micrographs with energy dispersive X-ray analysis (SEM-EDX) model (JEOL
JEM-100CX 11) carried out to determine the morphology and chemical composition of the ink box alloy and the corrosion layers. Examination of fracture surface determine the mode and direction of crack propagation. Fracture surface provides with important information helping to identify failure causes as material defects. The fracture surface examination at higher than about x20 and etching by means of alcoholic ferric chloride was carried out for microstructural analysis.

\subsection{X-Ray Diffraction Analysis (XRD)}

The box sample was analyzed to identify the corrosion products by X-ray powder diffraction (XRD) model (JEOL), under the following conditions: operating voltage: $U=35 \mathrm{kV}$, current $\mathrm{I}=30 \mathrm{~mA}, X$-rays from a copper cathode $(\mathrm{Cu})$, wavelength $\mathrm{Cu} \mathrm{K} \alpha=1.5418 \AA, 4-100^{\circ} 2 \theta$, step: $0.1^{\circ}$, Speed: $2 \%$ min.

\section{Results}

\subsection{Visual Examination}

Investigation of ink box revealed that the object consists of two parts which are the ink box cover and the box body, the ink box cover appeared missing parts in inlay layers with different coloured of corrosion products, cracks, and distortion the surface or warp which built up by cold-working. The body box revealed many blowholes and shrinkage Figure 2. The body box is made by hot-working or simplest mold. This technology is like sand casting [6].

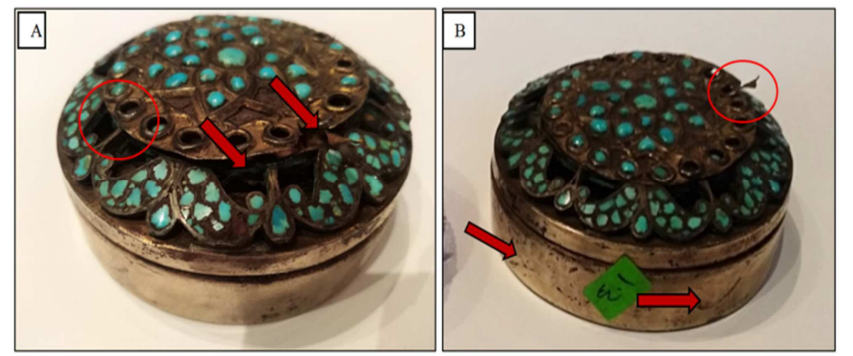

Figure 2. (2A) ink cover shows missing parts in inlay, corrosion products, cracks and distortion the surface or warps (2B) the body box shows blowholes and shrinkage.

\subsection{Scanning Electron Microscopy (SEM-EDX)}

SEM micrographs of fracture surface showed the presence of corrosion layers with different grain size, Figure 3 intergranular cracking and regions of ductile fracture and brittle. EDX Figure 4 and tables 1 and 2 determined chemical composition of the ink box alloy from 15.4\% silver Ag, 2.1\% copper $\mathrm{Cu}, 2.5 \% \mathrm{Zn}$ and the elemental corrosion layers from C, O, S, Cl, Si, Na, Ca, Al.

SEM micrographs of polishing surface sample and etching by alcoholic ferric chloride are showed crack propagation and pores Figure (5A) and cleavage fracture Figure (5B). 


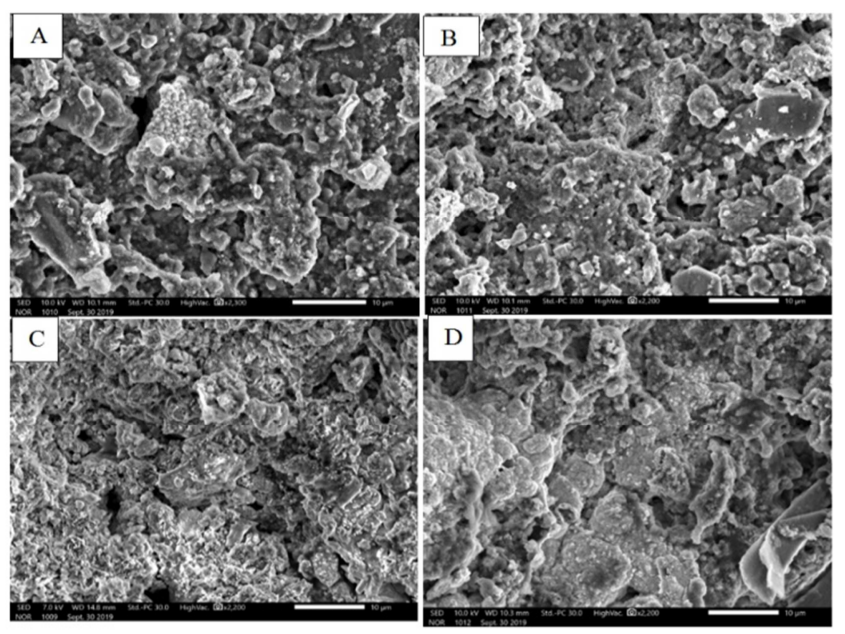

Figure 3. SEM micrograph showed fracture surface for interfacial cracking $(a, b)$ corrosion layers with different grain size, (c) intergranular cracking and regions of ductile fracture, (d) brittle intergranular fracture.

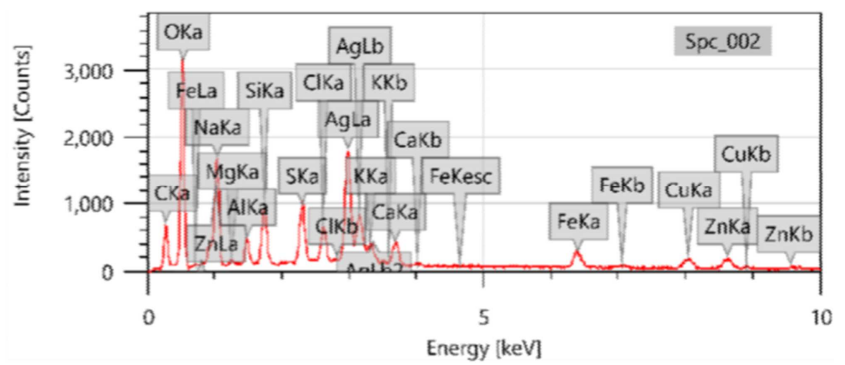

(a)

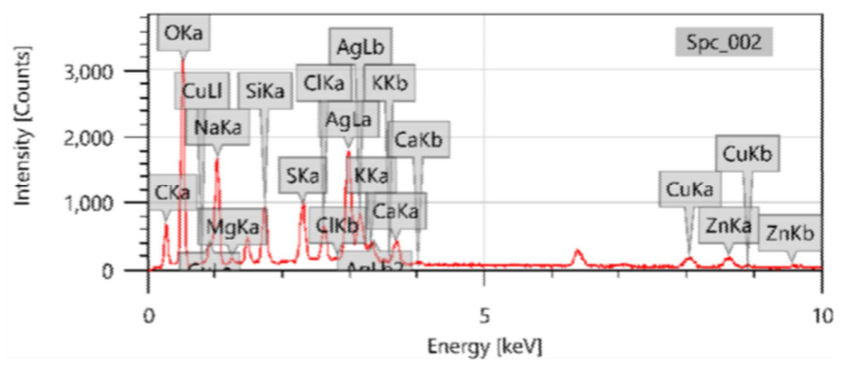

(b)

Figure 4. EDX of samples show the alloy consists of silver and copper and elemental corrosion layers from $\mathrm{C}, \mathrm{O}, \mathrm{S}, \mathrm{Cl}, \mathrm{Si}, \mathrm{Na}, \mathrm{Ca}$, and $\mathrm{Al}$.

Table 1. EDX of Sample analysis shows chemical composition of ink alloy.

\begin{tabular}{llll}
\hline Element & Line & Mass\% & Atom\% \\
\hline $\mathrm{C}$ & $\mathrm{K}$ & $16.24 \pm 0.15$ & $26.96 \pm 0.24$ \\
$\mathrm{O}$ & $\mathrm{K}$ & $43.46 \pm 0.31$ & $54.16 \pm 0.39$ \\
$\mathrm{Na}$ & $\mathrm{K}$ & $8.62 \pm 0.12$ & $7.47 \pm 0.11$ \\
$\mathrm{Mg}$ & $\mathrm{K}$ & $0.37 \pm 0.03$ & $0.31 \pm 0.02$ \\
$\mathrm{Al}$ & $\mathrm{K}$ & $1.23 \pm 0.04$ & $0.91 \pm 0.03$ \\
$\mathrm{Si}$ & $\mathrm{K}$ & $2.42 \pm 0.04$ & $1.72 \pm 0.03$ \\
$\mathrm{~S}$ & $\mathrm{~K}$ & $2.76 \pm 0.04$ & $1.72 \pm 0.02$ \\
$\mathrm{Cl}$ & $\mathrm{K}$ & $1.65 \pm 0.03$ & $0.93 \pm 0.02$ \\
$\mathrm{~K}$ & $\mathrm{~K}$ & $0.62 \pm 0.03$ & $0.32 \pm 0.01$ \\
$\mathrm{Ca}$ & $\mathrm{K}$ & $1.50 \pm 0.04$ & $0.75 \pm 0.02$ \\
$\mathrm{Fe}$ & $\mathrm{K}$ & $1.86 \pm 0.04$ & $0.67 \pm 0.02$ \\
$\mathrm{Cu}$ & $\mathrm{K}$ & $2.03 \pm 0.06$ & $0.64 \pm 0.02$ \\
$\mathrm{Zn}$ & $\mathrm{K}$ & $2.32 \pm 0.07$ & $0.71 \pm 0.02$ \\
\hline
\end{tabular}

\begin{tabular}{llll}
\hline Element & Line & Mass\% & Atom\% \\
\hline $\mathrm{Ag}$ & $\mathrm{L}$ & $14.92 \pm 0.13$ & $2.76 \pm 0.02$ \\
Total & & 100.00 & 100.00 \\
\hline
\end{tabular}

Table 2. EDX analysis on other Sample shows chemical composition of ink alloy.

\begin{tabular}{|c|c|c|c|}
\hline Element & Line & Mass\% & Atom\% \\
\hline $\mathrm{C}$ & $\mathrm{K}$ & $16.24 \pm 0.15$ & $26.60 \pm 0.24$ \\
\hline $\mathrm{O}$ & K & $45.39 \pm 0.32$ & $55.81 \pm 0.40$ \\
\hline $\mathrm{Na}$ & K & $8.87 \pm 0.13$ & $7.59 \pm 0.11$ \\
\hline $\mathrm{Mg}$ & K & $0.40 \pm 0.03$ & $0.32 \pm 0.02$ \\
\hline $\mathrm{Si}$ & K & $2.47 \pm 0.05$ & $1.73 \pm 0.03$ \\
\hline S & $\mathrm{K}$ & $2.83 \pm 0.04$ & $1.74 \pm 0.03$ \\
\hline $\mathrm{Cl}$ & K & $1.69 \pm 0.03$ & $0.94 \pm 0.02$ \\
\hline K & K & $0.64 \pm 0.03$ & $0.32 \pm 0.01$ \\
\hline $\mathrm{Ca}$ & K & $1.56 \pm 0.04$ & $0.77 \pm 0.02$ \\
\hline $\mathrm{Cu}$ & $\mathrm{K}$ & $2.10 \pm 0.06$ & $0.65 \pm 0.02$ \\
\hline $\mathrm{Zn}$ & K & $2.40 \pm 0.07$ & $0.72 \pm 0.02$ \\
\hline $\mathrm{Ag}$ & $\mathrm{L}$ & $15.39 \pm 0.13$ & $2.81 \pm 0.02$ \\
\hline Total & & 100.00 & 100.00 \\
\hline
\end{tabular}

Figure 5. SEM micrograph after etching revealed fatigue fracture surface (A) pores and crack propagation, (B) cleavage fracture.

\subsection{X-Ray Diffraction Analysis (XRD)}

X-Ray diffraction analysis Figure 6 and table 3 revealed the corrosion layers consisted of Montmorillonite as a major mineral, Atacamite, Malachite as minor minerals; and Paratacamite, Cuprite, Acanthite, Tenorite, Calcite, Chlorargyrite, Copper as traces minerals.

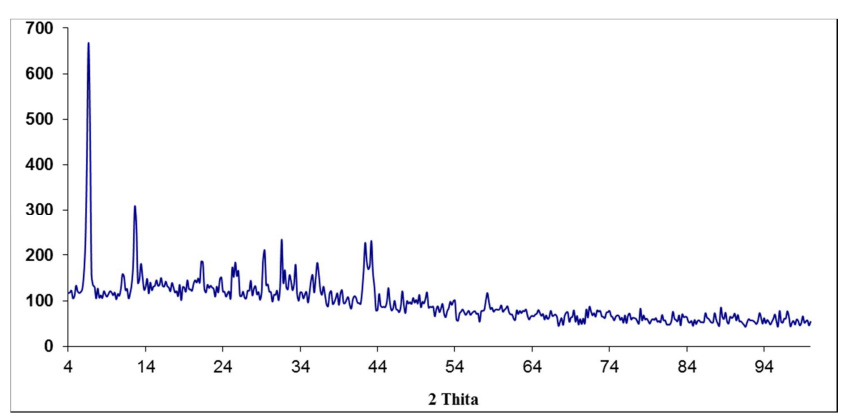

Figure 6. X-Ray diffraction analysis showed corrosion layers consisted of Montmorillonite as a major mineral, Atacamite, Malachite as minor minerals; and Paratacamite, Cuprite, Acanthite, Tenorite, Calcite, Chlorargyrite, Copper as traces minerals. 
Table 3. XRD analysis shows the chemical composition of corrosion layers.

\begin{tabular}{|c|c|c|c|c|}
\hline Mineral & Chemical structure & Formula & Card no. & Percentage \\
\hline Montmorillonite & Sodium magnesium Aluminum Silicate Hydroxide Hydrate & $\mathrm{NaO}_{3}(\mathrm{Al}, \mathrm{Mg})_{2} \mathrm{Si}_{4} \mathrm{O}_{10}(\mathrm{OH})_{2} \times \mathrm{H}_{2} \mathrm{O}$ & $13-0259$ & Major \\
\hline Atacamite & Copper Chloride Hydroxide & $\mathrm{Cu}_{2} \mathrm{Cl}(\mathrm{OH})_{3}$ & $02-0146$ & Minor \\
\hline Malachite & Copper Carbonate Hydroxide & $\mathrm{Cu}_{2} \mathrm{CO}_{3}(\mathrm{OH})_{2}$ & 10-0399 & Minor \\
\hline Paratacamite & Copper Chloride Hydroxide & $\mathrm{Cu}_{2} \mathrm{Cl}(\mathrm{OH})_{3}$ & $15-0694$ & Traces \\
\hline Cuprite & Copper Oxide & $\mathrm{Cu}_{2} \mathrm{O}$ & $05-0667$ & Traces \\
\hline Acanthite & Silver Sulfide & $\mathrm{Ag}_{2} \mathrm{~S}$ & $14-0072$ & Traces \\
\hline Tenorite & Copper Oxide & $\mathrm{CuO}$ & $05-0661$ & Traces \\
\hline Calcite & Calcium Carbonate & $\mathrm{CaCO}_{3}$ & $05-0586$ & Traces \\
\hline Chlorargyrite & Silver Chloride & $\mathrm{AgCl}$ & $06-0480$ & Traces \\
\hline copper & Copper & $\mathrm{Cu}$ & $01-1241$ & Traces \\
\hline
\end{tabular}

\section{Discussion}

Visual examination of silver copper ink box showed that the box made of two separate parts, the cover which made by cold-working and body box made by cast. The cover had layers of corrosion, miss in inlay layers, cracks, and distortion the surface or warp. The body box had blowholes and shrinkage in outer surface.

Examination by SEM micrograph revealed embrittlement in corrosion layers. The corrosion layers showed intergranular cracking and regions of ductile fracture. SEM micrograph reveal the object has undergone extensive plastic deformation, resulting in strain-hardening. SEM micrographs for etching sample showed pores and crack propagation.

Cold working (or strain-hardening) is a deformation of a metal below its recrystallisation temperature. With cold working the desired final shape is formed and the metal is simultaneously strengthened [11]. The strengthening or work hardening is the cause of the increasing number of dislocations. When the affected stress exceeds the yield strength, the dislocations in the metal begin to slip. Further increase of the applied stress indications to a visible distortion of the grains $[6,12]$.

SEM observation after etching revealed the cover of the box undergone extensive plastic deformation, resulting in strain-hardening and propagation of cracks. plastic deformation relates to the net movement of large numbers of atoms in response to an applied stress. During this process, interatomic bonds must be broken and then reformed. In crystalline solids, plastic deformation most often includes the motion of dislocations, linear crystalline defects [13].

Crack propagation is the main reason for unstable fracture of components. Complex working conditions such as corrosion, creep, excessive local strains, low frequency or high frequency vibration can increase crack initiation and propagation. Because of the randomness of micro crack growth orientation and rate, tracking of a controlled propagating cracks tip precisely are a subject of significant concern [14].

Pores in metals and alloys are as microcavities mostly a consequence of material shrinkage through the casting and solidification process and can be basically reflected as existing microcracks. pores developed in the phase distribution in two or multiphase materials, where cracks typically originate during dendritic solidification.
Different elastic properties or different coefficients of thermal expansion (CTE) of the parent material and the precipitates may increase the mechanical stress in the vicinity of the interface during mechanical or thermal loading and, eventually, produce interfacial crack initiation. The level of this stress increase depends strongly on the size of the inclusions. Normally, small non-metallic inclusions $(<5 \mu \mathrm{m})$ are believed as harmless for materials of low purity and components without special requirements on the surface finish $[5,15]$.

The EDX analysis reveals that the object is made of silver $\mathrm{Ag}$ that contains $\mathrm{Cu}$ and $\mathrm{Zn}$. Elements such as $\mathrm{C}, \mathrm{O}, \mathrm{Cl}, \mathrm{S}, \mathrm{Al}$, $\mathrm{Si}, \mathrm{Na}, \mathrm{K}, \mathrm{Ca}, \mathrm{Fe}$ observed at the corrosion layer of the object.

The XRD analysis confirmed the EDX analysis that the corrosion compounds consist of Montmorillonite $\mathrm{NaO}_{3}(\mathrm{Al}$, $\mathrm{Mg})_{2} \mathrm{Si}_{4} \mathrm{O}_{10}(\mathrm{OH})_{2} \mathrm{XH}_{2} \mathrm{O}$, Atacamite $\mathrm{Cu}_{2} \mathrm{Cl}(\mathrm{OH})_{3}$, Malachite $\mathrm{Cu}_{2} \mathrm{CO}_{3}(\mathrm{OH})_{2}$, Paratacamite $\mathrm{Cu}_{2} \mathrm{Cl}(\mathrm{OH})_{3}$, Cuprite $\mathrm{Cu}_{2} \mathrm{O}$, Acanthite $\mathrm{Ag}_{2} \mathrm{~S}$, Tenorite $\mathrm{CuO}$, Calcite $\mathrm{CaCO}_{3}$, Chlorargyrite $\mathrm{AgCl}$, Copper $\mathrm{Cu}$.

The occurrence in the sample of elements such as $\mathrm{Si}, \mathrm{Al}$, $\mathrm{Fe}, \mathrm{S}$ and $\mathrm{Cl}$ (plus oxygen in most of the cases) in the corrosion layers of the object can be indicated to likely superficial long-term contamination and oxidation, which led to the formation of secondary corrosion products.

Silver is very resistant to oxidation and this characteristic is related to strong intermetallic bonds and high energies of ionization. It is quite unaffected to the attack of $\mathrm{H}+($ Arrhenius and Bronsted acids) as it has a high standard electrode potential $\left(\mathrm{E}^{\circ}=+0.80 \mathrm{~V}\right)$ [16]. Copper is more

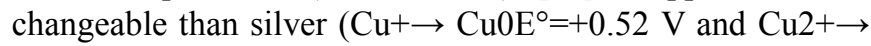
$\left.\mathrm{Cu} 0 \mathrm{E}^{\circ}=+0.34 \mathrm{~V}\right)$. The difference in the stability of these metals can indication to selective corrosion in the object they compose. Red and black oxides, green carbonates, sulfates, and chlorides of copper can be noticed due to the reaction of copper with gases in atmosphere or with corrosive solutions, depending on its storage. Despite the stability of silver, it may respond with oxygen and sulfur compounds $\left(\mathrm{H}_{2} \mathrm{~S}\right.$ or $\mathrm{COS})$ and humidity in atmosphere, generating a brownish-black tarnish on the surface of object. This tarnish can convert to black with time, and it is formed mostly of acanthite $\left(\mathrm{Ag}_{2} \mathrm{~S}\right)$. Sulfur compounds can also alter with copper generating black copper sulfides [17]. The presence of cuprite in the investigated samples may be explained by a high level of $\mathrm{CO}_{2}$ in the corrosion environments, whereas the 
combination of $\mathrm{SO}_{2}$ and $\mathrm{CO}_{2}$ helped the formation of sulphates and possibly sulphides [18].

\section{Conclusion}

Application of silver and its alloys was spread for making different vessels and other decorative and royal objects in historic time. Bullion (silver-copper alloy) ink box inlays with enamel from the Museum of the faculty of applied arts in Cairo, Egypt has been studied to identify manufacturing defects. Scanning Electron Microscopy coupled with Energy Dispersive X-ray Spectrometry (SEM-EDS) and XRD methods carried out to determined manufacturing defects which led to increase the corrosion processes. SEM micrograph illustrates the underlying mechanisms of the techniques that are used to strengthen and harden metal object. All objects contain some dislocations that were introduced during solidification, during plastic deformation, thermal stresses that result from rapid cooling. surface roughness occurs due to the manufacturing process or notches; surface protrusions cause the formation of pronounced (persistent) slip bands; second phases, precipitates or pores; and grain and phase boundaries, as the elastic and plastic anisotropy of the microstructure of polycrystalline materials. Pores in metals and alloys are as microcavities mostly a consequence of material shrinkage during the casting and solidification process and can be basically considered as existing microcracks. pores formed in the phase distribution in two or multiphase materials, where cracks typically emanate during dendritic solidification.

X-ray powder diffraction (XRD) shows the presence of atacamite, malachite, paratacamite, cuprite, acanthite, tenorite, calcite, chlorargyrite, native copper on the outer layers of the object. Mechanical damage of alloy depends on a variety of physical mechanisms acting in combination. These mechanisms influence each other and depend on the chemical composition and environmental conditions as temperature, partial pressures of gaseous species, humidity, microstructural features, heat-treatment conditions, and grain size. This paper recommends treatment and maintenance the object to remove stress, avoid moisture and galvanic cells, and reduce oxygen content by adding suitable corrosion inhibitors to provide cathodic protection and protect the metal parts exposed to corrosion.

\section{References}

[1] O. Omid, S. Atefeh, (2015). Chemical and microstructural analysis of some Achaemenian silver alloy artefacts from Hamedan, western Iran, Periodico di Mineralogia, 84, 3A (Special Issue), pp. 419-434.

[2] S. M. Northover, J. P. Northover, (2014) Microstructures of ancient and modern cast silver-copper alloys, Materials Characterization, 90, pp. 173-184.

[3] C. M. B. Martinsa, J. I. Martins, (2011). Identification of Corrosion Products on a Medieval Copper-Silver Coin,
Protection of Metals and Physical Chemistry of Surfaces, Vol. 47, No. 1, pp. 128-132.

[4] J. E. Hatch, Microstructure of Alloys, (1984). Aluminum Properties and Physical Metallurgy, ASM International, p. 58.

[5] U. Krupp, (2007). Fatigue Crack Propagation in Metals and Alloys: Microstructural Aspects and Modelling Concepts, Wiley-VCH Verlag GmbH \& Co. KGaA, Weinheim.

[6] Von der Fakultät für Werkstoffwissenschaft und Werkstofftechnologie, (2003). Material properties of copper alloys containing arsenic, antimony, and bismuth the material of Early Bronze Age ingot torques, $\mathrm{PhD}$, Technischen Universität Bergakademie Freiberg.

[7] D. Ashkenazi, N. Iddan, and O. Tal, (2012). Archaeometallurgical Characterization of Hellenistic Metal Objects: The Contribution of The Bronze Objects from Rishon Le-Zion, Archaeometry 54, 3, 528-548.

[8] A. A. Kassie, S. B. Assfaw, (2013). Minimalization of Casting Defects, IOSR Journal of Engineering. Vol. 3. Issue 5.

[9] L. Collini, (2012). Copper Alloys - Early Applications and Current Performance -Enhancing Processes, Manager Iva Simcic, Croatia.

[10] A. Gharib, F. S. Madkour, (2014). The Treatment Procedures of Persian Metallic Objects Covered with Colored Enamels, 18th - 20th Centuries AD, International Journal of Conservation Science, Volume 5, Issue 4, October-December: 447-458.

[11] Casting Defects-Sand Mould, Metal Casting, $\mathrm{http} / / / \mathrm{www}$.iron-foundry.com/casting-defects-pictures.html.

[12] Dislocations \& Strengthening Mechanisms Problem Solutions, $\mathrm{http} / / /$ www.acadox.com/action handler/download/resource/13 842/24821.pdf.

[13] R. Pippan1, C. Zelger, E. Gach, C. Bichler, and H. Weinhandl, (2010). On the mechanism of fatigue crack propagation in ductile metallic materials, Fatigue \& Fracture of Engineering Materials and Structures, 34, 1-16 1.

[14] Z. Ziming, L. Weiling, Y. Shaofeng, and B. J Juergen, (2015) Metal crack propagation monitoring by photoluminescence enhancement of quantum dots, Engineering and Laboratory Note, Vol. 54, No. 21, pp. 6498-6501.

[15] C. Pierre, V. Christophe, C. Christian, D. François, (2015). Effect of cold work, second phase precipitation and heat treatments on the mechanical properties of copper-silver alloys manufactured by cold spray, Materials Science and Engineering A 637, 40-47.

[16] Y. Z. Tian, and Z. F. Zhang, (2009). Microstructures and tensile deformation behavior of $\mathrm{Cu}-16 \mathrm{wt} . \% \mathrm{Ag}$ binary alloy, Materials Science and Engineering A, www.reserchgate.net/publication/240423160.

[17] J. C. D. de Figueiredo, S. S. Asevedo, J. H. Barbosa, (2014). Removal of brownish-black tarnish on silver-copper alloy objects with sodium glycinate, Applied Surface Science 317, $67-72$.

[18] G. Balassone et al. (2018). Multi-analytical characterization and provenance identification of protohistoric metallic artefacts from Picentia- Pontecagnano and the Sarno valley sites, Campania, Italy, Measurement 128, 104-118. 